\title{
Idiopathic palmar fasciitis and polyarthritis syndrome
}

\author{
Katsunobu Yoshioka (1) , ${ }^{1}$ Takaya Fukumoto, ${ }^{2}$ Junko Sowa-Osako, ${ }^{3}$ Chiharu Tateishi ${ }^{3}$
}

${ }^{1}$ Internal Medicine, Shitennoji Hospital, Osaka, Japan ${ }^{2}$ Dermatology, Fukumoto Dermatology Clinic, Nara, Japan ${ }^{3}$ Dermatology, Osaka City University Graduate School of Medicine School of Medicine, Osaka, Japan

\section{Correspondence to}

Dr Katsunobu Yoshioka; kyoshioka@shitennoji-fukushi.jp

Accepted 15 October 2019

\section{DESCRIPTION}

A 79-year-old man presented to our hospital with 2-month history of difficulty in flexing and extending all fingers of both hands. Three years previously, he was diagnosed as having monoclonal gammopathy of undetermined significance (MGUS) and was followed-up without progression to multiple myeloma. On physical examination, the patient had thick and tight flexion contractures of both hands (woody hands) with mild oedema (figure 1A,B). The remainder of the physical examination was unremarkable. He had no history of Raynaud's phenomenon. C reactive protein was $0.07 \mathrm{mg} / \mathrm{dL}$. Serum Ig levels were as follows: IgG $2087 \mathrm{mg} / \mathrm{dL}$, IgA $264 \mathrm{mg} / \mathrm{dL}$ and IgM $32 \mathrm{mg}$ dL. Immunoelectrophoresis revealed IgG- $\kappa$ type M-protein. Serum-free light chain analysis showed a mild raised $\kappa / \lambda$ ratio of 1.76 (normal range: $0.26-1.65)$. A bone marrow aspiration revealed $1.6 \%$ of plasma cells with atypia such as flame cells, grape cells and giant plasma cells. These findings are compatible with the diagnosis of MGUS. We suspected the likelihood of amyloidosis. However, biopsy of the duodenum was negative for Congo red stain. A test for antinuclear antibodies was positive at a titer of 1:40, with a speckled pattern. However, test for Scl-70 antibody was negative and Raynaud's phenomenon was absent. Therefore, the patient did not meet the criteria for the diagnosis of scleroderma. At this point, we suspected the likelihood of palmar fasciitis and polyarthritis syndrome (PFPAS), and a deep skin biopsy from the dorsum of the right hand was done, which revealed severe thickness of the fascia (figure 1C double-headed

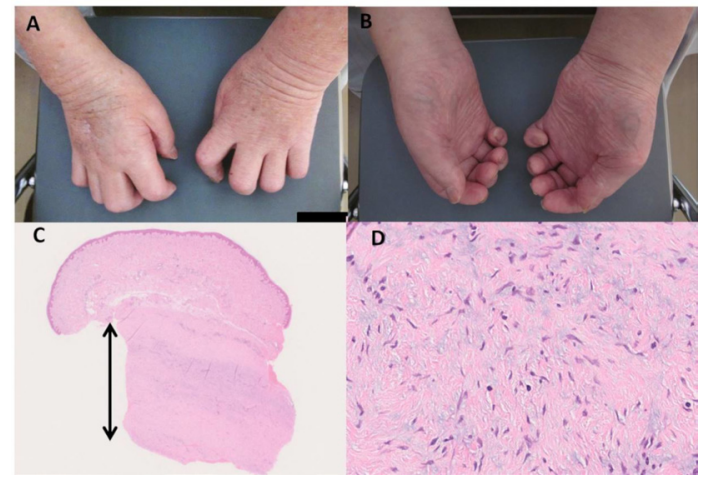

Figure 1 The patient had thick and tight flexion contractures of both hands (woody hands) with mild oedema $(A, B)$. Skin biopsy from the dorsum of the right hand revealed severe thickness of the fascia $((C)$ doubleheaded arrow) with increase of fibroblast-like spindle cells and collagen fibres (D). arrow) with increase of fibroblast-like spindle cells and collagen fibres (figure 1D), and scarce infiltration of inflammatory cells. A stain for Congo red stain was negative. Thus, a diagnosis of PFPAS was made. PFPAS is regarded as paraneoplastic syndrome, characterised by flexion contractures of both hands and thickening of palmar fascia. ${ }^{1}$ Therefore, we performed whole body screening for malignancies such as whole body CT, upper and lower gastrointestinal endoscopy and measurement of tumour markers. However, thorough examinations of the entire body could not identify any evidence of malignancy. Thus, PFPAS was currently considered idiopathic. Until now, only two patients with idiopathic PFPAS have been reported. ${ }^{23}$ However, PFPAS can occur months to years before the detection of malignancy and appears unrelated to the tumour stage. Therefore, he is currently under close follow-up for development of malignancy in the future.

\section{Learning points}

Palmar fasciitis and polyarthritis syndrome (PFPAS) is an uncommon disorder characterised by progressive flexion contractures of both hands and regarded as paraneoplastic syndrome.

- Our image captures the macroscopic characteristics of PFPAS, that is, tight flexion contractures of both hands, also known as 'woody hands'.

- We believe that this report will increase awareness about PFPAS among physicians.

Contributors $\mathrm{KY}$ reviewed medical records, interpreted data and drafted the manuscript. TF and JS-O reviewed the pathology of the skin and supervised the study. CT reviewed medical records, interpreted data and supervised the study.

Funding The authors have not declared a specific grant for this research from any funding agency in the public, commercial or not-for-profit sectors.

Competing interests None declared.

Patient consent for publication Obtained.

Provenance and peer review Not commissioned; externally peer reviewed.

ORCID iD

Katsunobu Yoshioka http://orcid.org/0000-0002-5568-8629

\section{REFERENCES}

1 Medsger TA, Dixon JA, Garwood VF. Palmar fasciitis and polyarthritis associated with ovarian carcinoma. Ann Intern Med 1982;96:424-31.

2 Laszlo KS, Falanga V, Kerdel FA. Idiopathic palmar fasciitis. Int J Dermatol 1995;34:658-60.

3 Sung Y-K, Park M-H, Yoo D-H. Idiopathic palmar fasciitis with polyarthritis syndrome. J Korean Med Sci 2006;21:1128-32. 
Copyright 2019 BMJ Publishing Group. All rights reserved. For permission to reuse any of this content visit https://www.bmj.com/company/products-services/rights-and-licensing/permissions/

BMJ Case Report Fellows may re-use this article for personal use and teaching without any further permission.

Become a Fellow of BMJ Case Reports today and you can:

- Submit as many cases as you like

Enjoy fast sympathetic peer review and rapid publication of accepted articles

Access all the published articles

Re-use any of the published material for personal use and teaching without further permission

Customer Service

If you have any further queries about your subscription, please contact our customer services team on +44 (0) 2071111105 or via email at support@bmj.com.

Visit casereports.bmj.com for more articles like this and to become a Fellow 